\title{
AMS RADIOCARBON DATING PROBLEMS BETWEEN 10 AND 8 KA BP IN LACUSTRINE DEPOSITS FROM LAKE GUN NUR, NORTHERN MONGOLIA
}

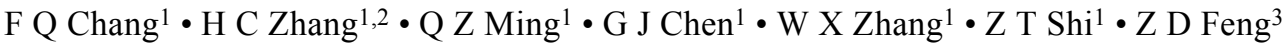

ABSTRACT. Accelerator mass spectrometry (AMS) radiocarbon dating a continuous core from Lake Gun Nur, northern Mongolia, shows a period between 10 and $8 \mathrm{ka}$ BP that could not be dated accurately. Further dating on alkali-insoluble residue and humic acid from the same samples in the Gun Nur core suggest that this AMS ${ }^{14} \mathrm{C}$ date anomaly is neither analytical nor material related. We hypothesize that the ${ }^{14} \mathrm{C}$ anomaly may be derived from increasing production rates of ${ }^{14} \mathrm{C}$ caused by diminished solar activity, a low ${ }^{14} \mathrm{CO}_{2} /{ }^{14} \mathrm{CO}$ ratio in the atmosphere, or an unstable ${ }^{14} \mathrm{C}$ flux in the lower atmosphere caused by changing geomagnetic field strength. Our results imply that the ${ }^{14} \mathrm{C}$ data used for ${ }^{14} \mathrm{C}$ age calibration cannot correct the agedepth regression between 8 and $10 \mathrm{ka} \mathrm{BP}$ to fit the age-depth model along with other time intervals.

\section{INTRODUCTION}

Radiocarbon dating of lacustrine sediments formed during the early Holocene is problematic. For example, ${ }^{14} \mathrm{C}$ dates in core SO89-17 from Lake Soppensee, central Switzerland, are distributed unevenly and changed dramatically between 7000 and $9000{ }^{14} \mathrm{C}$ yr BP, especially between 8200 and $9000{ }^{14} \mathrm{C}$ yr BP (Hajdas et al. 1993). In Lake Suigetsu, Japan (Kitagawa and van der Plicht 1998), the largest age reversals appeared between $1040 \sim 1354 \mathrm{~cm}$ in depth, corresponding to 8000 10,000 cal yr BP. A similar problem occurs in the ${ }^{14} \mathrm{C}$ dates in core IK97-11P from Lake Issyk-Kul, Kyrgyzstan, from $337-340 \mathrm{~cm}$ core depth $\left({ }^{14} \mathrm{C}\right.$ dated at $\left.8940 \pm 65 ; 8670 \pm 60 \mathrm{yr} \mathrm{BP}\right)$, and IK97-10P, depth $339-342 \mathrm{~cm}\left({ }^{14} \mathrm{C}\right.$ dated at $\left.8310 \pm 45 ; 8410 \pm 45 \mathrm{yr} \mathrm{BP}\right)$, before being corrected, are unreasonable, though there is no indication of a problem from the isotope or trace element results (Ricketts et al. 2001). In the Huguang Maar Lake in southern China, leaf samples Kia8832 and Kia8833 were dated at $7670 \pm 100$ and $7880+230 /-220 \mathrm{yr}^{14} \mathrm{C} \mathrm{BP}$, which are considered to be too young (Mingram et al. 2004). This dating problem may also be present in marine deposits (Bard et al. 1989), because the ${ }^{14} \mathrm{C}$ ages of deep-water and surface-water reservoirs, which are currently assumed to be $\sim 400 \mathrm{yr}$ in the tropics and $\sim 1200 \mathrm{yr}$ in Antarctica, might vary through time (Bard et al. 1994) and from place to place (Sikes et al. 2000). In a similar manner, we also observed the ${ }^{14} \mathrm{C}$ age uncertainty between 10 and $8 \mathrm{ka} \mathrm{BP}$ when we investigated Lake Gun Nur, northern Mongolia $\left(50^{\circ} 15^{\prime} \mathrm{N} ; 106^{\circ} 37^{\prime} \mathrm{E}\right)$, for a paleoclimate change study.

\section{METHODS}

A 748-cm-long continuous core from Lake Gun Nur in northern Mongolia was retrieved using piston-coring equipment. Two parallel cores were taken at the center of the lake at $4.6 \mathrm{~m}$ water depth. The cores were cut in half and sediments found to be largely undisturbed. After all segments were described carefully, they were combined into 1 complete core section based on their shared depositional characteristics, such as sedimentary structures, color, fossils, etc. Except in the upper $6 \mathrm{~cm}$, the cores were sampled at $1-\mathrm{cm}$ intervals for geochemical analyses and at 2-cm intervals for pollen and microfossil analyses. ${ }^{14} \mathrm{C}$ dating by accelerator mass spectrometry (AMS) yielded a high-resolution chronology. In total, 45 samples were dated by 3 AMS laboratories: the Leibniz Laboratory for Radiometric Dating and Stable Isotope Research (Kiel, Germany); Beta Analytic Inc. (Miami, USA); and the University of Arizona AMS facility (Tucson, USA).

\footnotetext{
${ }^{1}$ Key Laboratory of Plateau Lake Ecology and Global Change, College of Tourism and Geography, Yunnan Normal University, No. 1 Yuhua District, Chenggong, 650500 Kunming, China.

${ }^{2}$ Corresponding author. Email: hucaizhang@yahoo.com.

${ }^{3}$ Department of Geology, Baylor University, Waco, Texas 76712, USA.
} 
Ten samples were sent to Kiel in which ages for both the alkali residue (AR) and humic acid (HA) fractions were obtained. All were sampled at $1-\mathrm{cm}$ intervals. X-ray and SEM analyses were conducted in the Institute of Physical Geography, Free University of Berlin, Germany.

\section{RESULTS}

\section{Dating Results}

All dates were reproduced (at $2 \sigma$ ) by the 3 laboratories, except the ages between the depths of 670 and $460 \mathrm{~cm}$ (Figure 1a; Table 1-3). In this interval of the core, the dates differ from each other, changing the general age-depth regression trend, and forming what we informally term the Age Uncertainty Plateau, or AUP. Only 6 of 17 dates fall along the expected regression line predicted by uniform sedimentation rates (Figure 1b; Table 1-3). All dates not from the AUP interval are considered reliable because the measurements from 3 different laboratories agree well.

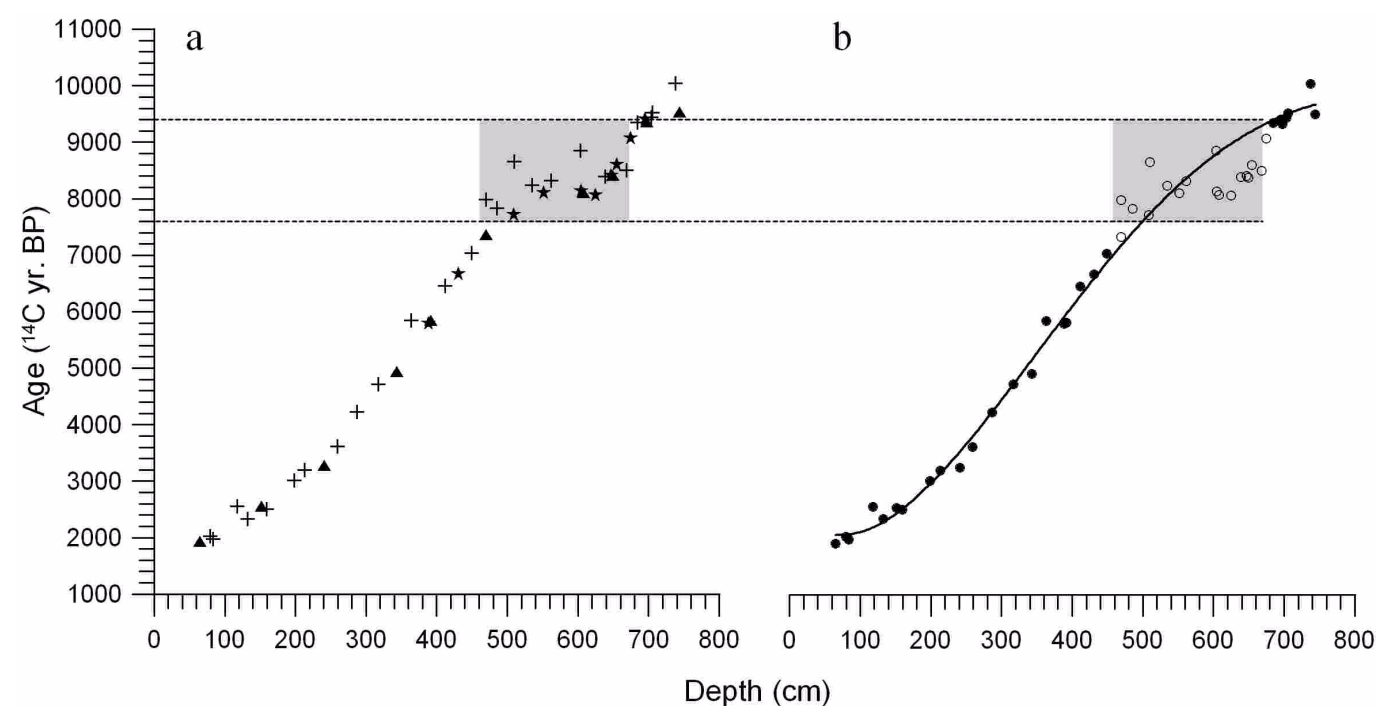

Figure $1{ }^{14} \mathrm{C}$ age-depth plot of the Lake Gun Nur core: a) triangles (Beta Analytic); crosses (Arizona); stars (Kiel). b) Age-depth and regression line excluding dates between 467 and $670 \mathrm{~cm}$ (circles). The shaded area marks the 210-cmthick zone of anomalous ${ }^{14} \mathrm{C}$ dates.

\section{Core Stratigraphy and Geochemistry}

A detailed examination of the physical, mineralogical, and geochemical features of the Gun Nur core suggests that there is no hiatus nor unconformity, such as features from earthquakes, bioturbation, or erosion (Figure 2), especially between the depths of 460 and $670 \mathrm{~cm}$ (Wang et al. 2004). Because abundant benthic diatoms were observed between 450 and $720 \mathrm{~cm}$ (Feng et al. 2005) and carbonate-rich laminated layers were observed between 570 and $720 \mathrm{~cm}$ (Figure 3), which are composed of almost pure aragonite crystals, the depositional environment was deemed stable. All these observations, combined with the even, flat lake bottom and relatively uniform sedimentation rates, rule out the possibility of sudden or abnormal depositional and geochemical processes. To test the possible postdepostional translocation of humates through lake sediment, 10 paired ages of both humic acid (HA) and alkali-insoluble residue (AR) fractions of organic matter were dated. The sediments are rich in organic matter (13-21.7\%), and thus are believed to overwhelm the presence of 
Table 1 AMS ${ }^{14} \mathrm{C}$ dates of organic matter by Arizona AMS facility $(2 \sigma) .^{\mathrm{a}}$

\begin{tabular}{llllllll}
\hline Lab nr & $\begin{array}{l}\text { Depth } \\
(\mathrm{cm})\end{array}$ & $\begin{array}{l}\text { Depth-C } \\
(\mathrm{cm})\end{array}$ & $\begin{array}{l}{ }^{14} \mathrm{C} \text { age } \\
\mathrm{BP}\end{array}$ & $\begin{array}{l}\delta^{13} \mathrm{C} \\
(\%)\end{array}$ & $\begin{array}{l}\text { cal }{ }^{14} \mathrm{C} \text { age } \\
\text { BP }\end{array}$ & $\begin{array}{l}\text { Midpoint } \\
\text { cal BP }\end{array}$ & Material \\
\hline AA51939 & $79-80$ & 79.5 & $2030 \pm 37$ & -15.8 & $1890-2120$ & 2005 & Org. \\
AA51940 & $83-84$ & 83.5 & $1975 \pm 41$ & -17 & $1820-2010$ & 1915 & Org. \\
AA51941 & $117-118$ & 117.5 & $2560 \pm 37$ & -17.4 & $2490-2760$ & 2625 & Org. \\
AA51942 & $132-133$ & 132.5 & $2338 \pm 37$ & -20.9 & $2300-2500$ & 2400 & Org. \\
AA51943 & $159-160$ & 159.5 & $2500 \pm 140$ & -16.1 & $2300-2950$ & 2625 & Org. \\
AA51944 & $198-199$ & 198.5 & $3016 \pm 39$ & -21.6 & $3070-3350$ & 3210 & Org. \\
AA51945 & $212-214$ & 213 & $3201 \pm 38$ & -16.2 & $3340-3480$ & 3410 & Org. \\
AA51946 & $258-260$ & 259 & $3617 \pm 40$ & -19.9 & $3820-4000$ & 3910 & Org. \\
AA51947 & $286-288$ & 287 & $4226 \pm 42$ & -17.4 & $4610-4870$ & 4740 & Org. \\
AA51948 & $316-318$ & 317 & $4721 \pm 44$ & -14.8 & $5320-5590$ & 5455 & Org. \\
AA51949 & $363-364$ & 363.5 & $5843 \pm 47$ & -9.4 & $6350-6760$ & 6555 & Org. \\
AA51950 & $411-412$ & 411.5 & $6458 \pm 47$ & -15.1 & $7270-7440$ & 7355 & Org. \\
AA51951 & $448-450$ & 449 & $7040 \pm 61$ & -10.3 & $7720-7970$ & 7845 & Org. \\
AA51952 & $469-470$ & 469.5 & $7991 \pm 69$ & -8 & $8630-9030$ & 8830 & Org. \\
AA51953 & $485-486$ & 485.5 & $7836 \pm 63$ & -5.2 & $8400-9000$ & 8700 & Org. \\
AA51954 & $509-510.3$ & 509.7 & $8660 \pm 66$ & -11.5 & $9520-9900$ & 9710 & Org. \\
AA51955 & $534-535$ & 534.5 & $8242 \pm 63$ & -5.6 & $9020-9430$ & 9225 & Org. \\
AA51956 & $561-562$ & 561.5 & $8324 \pm 63$ & -5.6 & $9130-9490$ & 9310 & Org. \\
AA51957 & $603-604$ & 603.5 & $8858 \pm 83$ & -11 & $9600-10,250$ & 9925 & Org. \\
AA51958 & $638-639$ & 638.5 & $8397 \pm 62$ & -16.4 & $9270-9530$ & 9400 & Org. \\
AA51959 & $668-669$ & 668.5 & $8500 \pm 60$ & -15 & $9400-9560$ & 9480 & Org. \\
AA51960 & $684-685$ & 684.5 & $9356 \pm 64$ & -21 & $10,360-10,750$ & 10,555 & Org. \\
AA51961 & $703-704$ & 703.5 & $9439 \pm 88$ & -14.7 & $10,400-11,100$ & 10,750 & Org. \\
AA51962 & $705-706$ & 705.5 & $9528 \pm 58$ & -28.9 & $10,500-11,150$ & 10,825 & Org. \\
AA51963 & $737-738$ & 737.5 & $10,047 \pm 70$ & -27.6 & $11,200-12,100$ & 11,650 & Org. \\
\hline
\end{tabular}

anote: Depth-C refers to the center depth of sample.

Table 2 AMS ${ }^{14} \mathrm{C}$ dates of organic matter by Beta Analytic. ${ }^{\mathrm{a}}$

\begin{tabular}{llllllrl}
\hline Lab nr & $\begin{array}{l}\text { Depth } \\
(\mathrm{cm})\end{array}$ & $\begin{array}{l}\text { Depth-C } \\
(\mathrm{cm})\end{array}$ & $\begin{array}{l}{ }^{14} \mathrm{C} \text { age } \\
\text { BP }\end{array}$ & $\begin{array}{l}\delta^{13} \mathrm{C} \\
(\%)\end{array}$ & $\begin{array}{l}\text { cal }{ }^{14} \mathrm{C} \text { age } \\
\text { BP }\end{array}$ & $\begin{array}{l}\text { Midpoint } \\
\text { cal BP }\end{array}$ & Matter \\
\hline Beta-171822 & $64-65$ & 64.5 & $1900 \pm 40$ & -23.1 & $1710-1930$ & 1820 & Org. \\
Beta-171823 & $151-152$ & 151.5 & $2530 \pm 40$ & -24.1 & $2470-2750$ & 2610 & Org. \\
Beta-171824 & $240-242$ & 241 & $3250 \pm 40$ & -21 & $3380-3570$ & 3475 & Org. \\
Beta-171826 & $342-344$ & 343 & $4910 \pm 40$ & -22.7 & $5590-5730$ & 5660 & Org. \\
Beta-198046 & $469-470$ & 469.5 & $7330 \pm 50$ & -21.2 & $8010-8200$ & 8105 & Org. \\
Beta-198047 & $607-608$ & 607.5 & $8080 \pm 50$ & -23.5 & $8800-8820$ & 8810 & Org. \\
Beta-198048 & $649-650$ & 649.5 & $8380 \pm 50$ & -25.9 & $9500-9280$ & 9390 & Org. \\
Beta-198049 & $697-698$ & 697.5 & $9330 \pm 50$ & -24.5 & $10,670-10,400$ & 10,535 & Org. \\
Beta-171827 & $743-744$ & 743.5 & $9500 \pm 50$ & -26.8 & $10,500-11,100$ & 10,800 & Wood \\
\hline
\end{tabular}

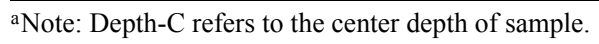

old residue carbon in sediment. Because organic carbon contents in the Gun Nur core are extremely high (average content $>18 \%$ ) and $\delta^{13} \mathrm{C}$ values are low $(<-25 \%$ ), suggesting terrestrial plants dominate the lake organic matters, the hardwater reservoir effect on our ${ }^{14} \mathrm{C}$ dating could be minimal. 


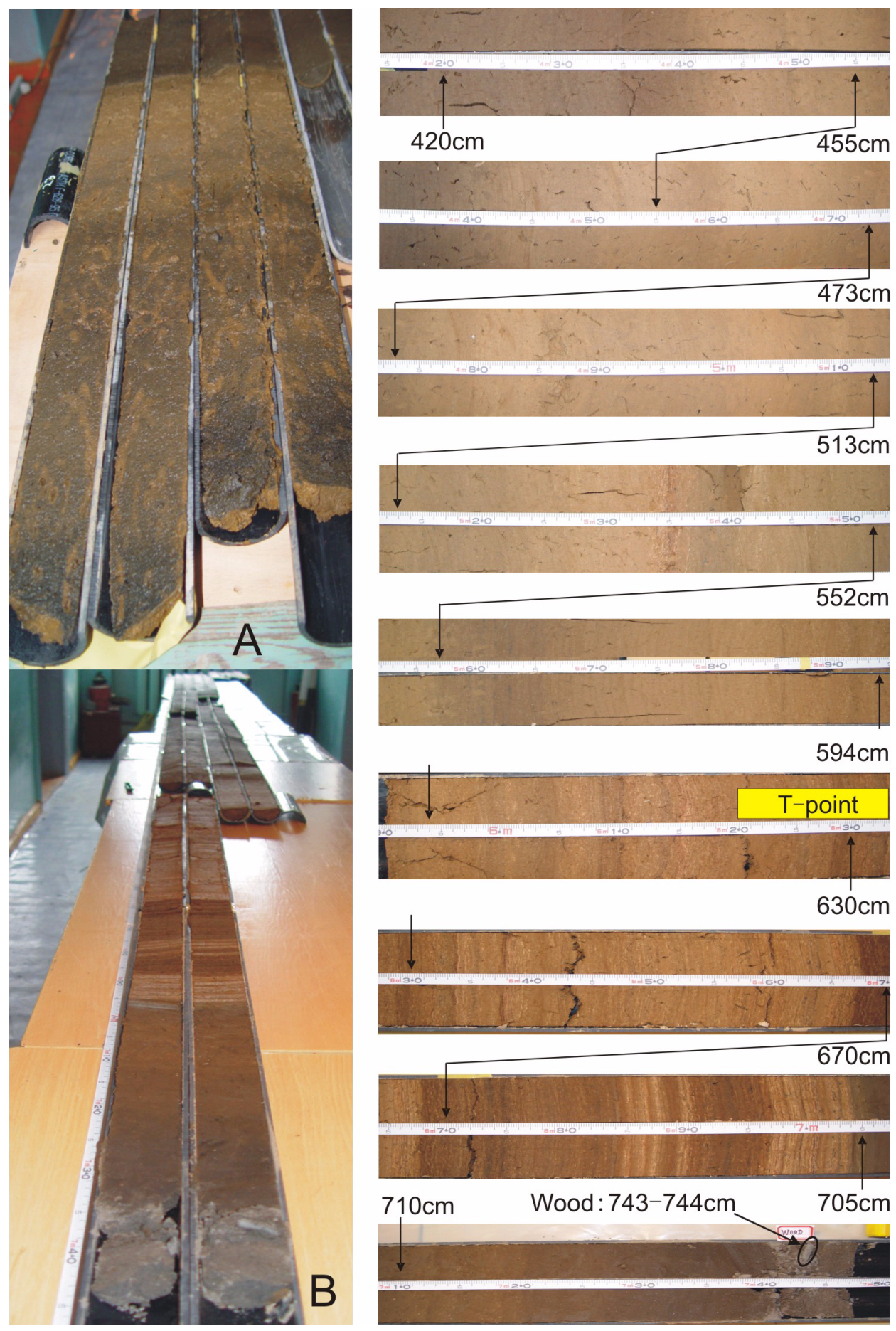

Figure 2 A detailed picture of the core stratigraphy, left column: fresh cores viewed from the top (A) and from the bottom (B); right column, the core from $\sim 4.2 \mathrm{~m}$ to the bottom (T-point marks the reverse point of AMS ${ }^{14} \mathrm{C}$ ages; see also Figures 3 and 4 ). 


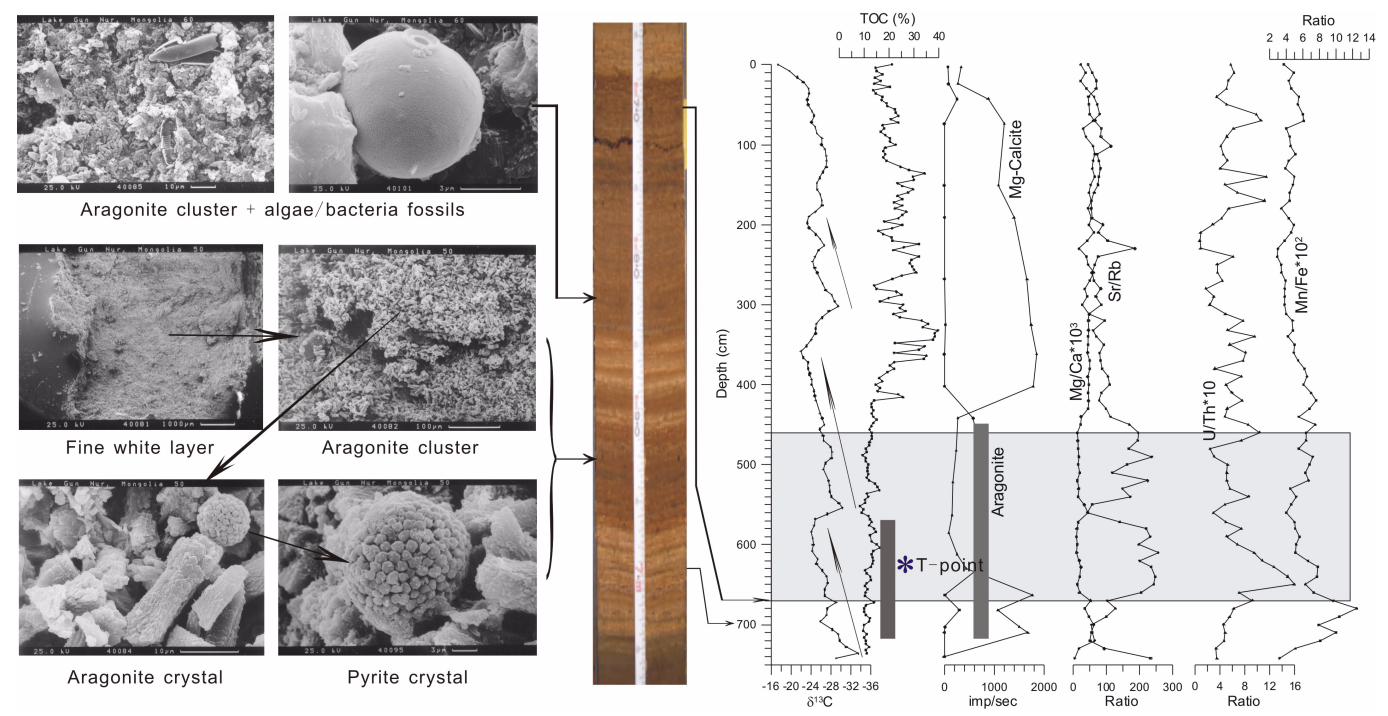

Figure 3 Left: photographs of some mineralogical and biological features of the core. Middle: well-stratified layers from the lower part of the core. Right: geochemical analyses vertical of the entire core. The shaded area denotes the $210-\mathrm{cm}-$ thick portion of the core with anomalous ${ }^{14} \mathrm{C}$ dates. The longer bar denotes a zone of dominantly benthic foraminiferous layers, and the shorter vertical bar is a zone of well-stratified layers.

The dates of the humic acid (HA) fraction in all cases are older than that of the alkali-insoluble residue (AR; Table 3, Figure 4). Theoretically, the organic matter in lacustrine deposits, which are different from the soil matter, in both soluble and insoluble fractions, were formed at the same time and thus should give the same dates. Different ages given by HA and AR fractions of the same sample imply either the AR fraction was derived from the old organic matter or the HA fraction was mobile in the sediments. Therefore, the age differences between HA and AR could be used as a criterion to evaluate the reliability of AMS ${ }^{14} \mathrm{C}$ dates (Zhang et al. 2008). In the Gun Nur core, the older dates of the HA fraction indicate upward movement of the soluble organic matter, perhaps due to soft-sediment consolidation. The upward movement of HA could be absorbed by sediments, and HA could also be fused or "condensed" with the AR organic compounds through humification processes.

Table 3 AMS ${ }^{14} \mathrm{C}$ dates of humic acid (HA) and alkali residue (AR) fractions by Kiel. ${ }^{\mathrm{a}}$

\begin{tabular}{lllllllll}
\hline Lab nr & $\begin{array}{l}\text { Depth } \\
(\mathrm{cm})\end{array}$ & $\begin{array}{l}\text { Depth-C } \\
(\mathrm{cm})\end{array}$ & $\begin{array}{l}\text { Age BP } \\
\text { (AR) }\end{array}$ & $\begin{array}{l}\delta^{13} \mathrm{C} \\
(\%)\end{array}$ & $\begin{array}{l}\text { cal age } \\
\text { yr BP } \\
(\mathrm{AR})\end{array}$ & $\begin{array}{l}\text { Age } \\
\text { yr BP } \\
(\mathrm{HA})\end{array}$ & $\begin{array}{l}\delta^{13} \mathrm{C} \\
(\%)\end{array}$ & Matter \\
\hline KIA25401 & $388-389$ & 388.5 & $5795 \pm 30$ & -17 & 6583 & $5815 \pm 30 / 35$ & -17.82 & Org. \\
KIA25402 & $430-431$ & 430.5 & $6670 \pm 30$ & -20.81 & 7533 & $6790 \pm 45$ & -21.42 & Org. \\
KIA25403 & $508-509$ & 508.5 & $7725 \pm 35$ & -22.82 & 8480 & $8050 \pm 40$ & -24.01 & Org. \\
KIA25404 & $551-552$ & 551.5 & $8105 \pm 35$ & -22.92 & 9044 & $8425 \pm 35$ & -23.72 & Org. \\
KIA23783 & $604-605$ & 604.5 & $8135 \pm 45$ & -23.93 & 9073 & $8340 \pm 45$ & -24.03 & Org. \\
KIA23782 & $624-625$ & 624.5 & $8065 \pm 40$ & -25.14 & 9033 & $8155 \pm 40$ & -23.51 & Org. \\
KIA23781 & $646-647$ & 646.5 & $8415 \pm 45$ & -25.32 & 9465 & $8655 \pm 45$ & -24.59 & Org. \\
KIA23780 & $654-655$ & 654.5 & $8610 \pm 45$ & -24.3 & 9613 & $8800 \pm 45$ & -25.86 & Org. \\
KIA23779 & $674-675$ & 674.5 & $9075 \pm 45$ & -26.08 & 10,224 & $9200 \pm 45$ & -26.21 & Org. \\
KIA23778 & $694-695$ & 694.5 & $9409 \pm 46$ & -21.13 & 10,624 & $9505 \pm 60$ & -25.05 & Org. \\
\hline
\end{tabular}

aNote: Depth-C refers to the depth of the sample center. 


\section{DISCUSSION}

We attributed the anomalous ${ }^{14} \mathrm{C}$ dates between 460 and $670 \mathrm{~cm}$ (Figure $4 \mathrm{a}$ ) to changes in ${ }^{14} \mathrm{C}$ production rates. Thus, we predict the same reason for similar discrepancies in other high-resolution lacustrine records discussed in the Introduction.
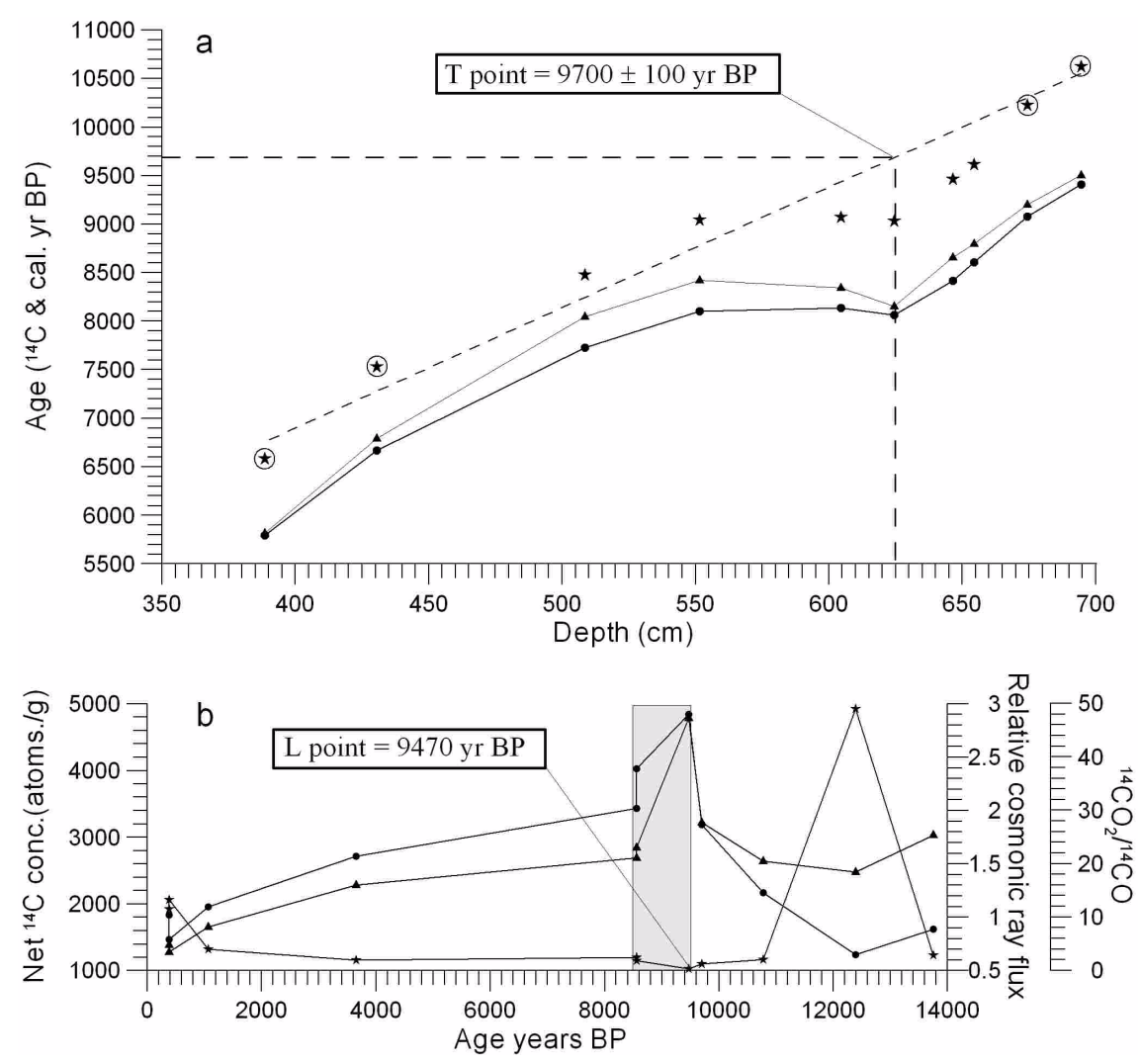

Figure 4 a) AMS ${ }^{14} \mathrm{C}$ ages between 380 and $700 \mathrm{~cm}$ in the core. Dotted line: age of alkali residue (AR); Triangle line: age of humic acid fraction (HA); Stars: calibrated ages given by AR fraction. The age at T-point was calculated according to the linear regression (dashed line) based on the 4 circled dates. Both ${ }^{14} \mathrm{C}$ and cal yr BP are given in the vertical axis. b) $\mathrm{Net}^{14} \mathrm{C}$ concentration (triangle line), relative cosmic-ray flux (dotted line), and ${ }^{14} \mathrm{CO}_{2} /{ }^{14} \mathrm{CO}$ ratio (star line) during the last $14,000 \mathrm{yr}$ recorded in an ice core at Summit, Greenland. The L-point marks the lowest value of ${ }^{14} \mathrm{CO}_{2} /{ }^{14} \mathrm{CO}$ ratio (data after Lal et al. 2005).

The concentration of in situ cosmogenic ${ }^{14} \mathrm{C}$ in ice crystals at Summit in Greenland shows that on a century timescale, the cosmic-ray-induced production rate of ${ }^{14} \mathrm{C}$ was higher by about a factor of 2 during 9500-8500 yr BP (Figure 4b), attributed to the low solar activity resulting in variable modulation of terrestrial cosmic-ray flux (Lal et al. 2005). An age of $9470 \mathrm{yr}$ BP for the L-point in Figure $4 \mathrm{~b}$ is comparable to that of the T-point in Figure 4a, $9700 \pm 100 \mathrm{yr}$ BP. Though the data density is low, one can deduce that the high net ${ }^{14} \mathrm{C}$ concentration and relative cosmic-ray flux between 8500 and $9500 \mathrm{yr}$ BP should result in a high ${ }^{14} \mathrm{C}$ value in the atmosphere over the Northern Hemisphere. However, the atmospheric ${ }^{14} \mathrm{C}$ in the ice record includes both ${ }^{14} \mathrm{CO}_{2}$ and ${ }^{14} \mathrm{CO}$, whereas tree-ringdeduced ${ }^{14} \mathrm{C}$ is only associated with ${ }^{14} \mathrm{CO}_{2}$ because ${ }^{14} \mathrm{CO}$ cannot be taken up during plant photosynthesis. These processes can be described by the following equations: 
radioactive carbon formation in the atmosphere:

$$
{ }^{14} \mathrm{~N}+n \rightarrow{ }^{14} \mathrm{C}+p \rightarrow{ }^{14} \mathrm{CO}+{ }^{14} \mathrm{CO}_{2} ;
$$

building of the carbon isotopes in plant tissues through photosynthesis:

$$
6 \mathrm{CO}_{2}\left({ }^{14} \mathrm{CO}_{2}+{ }^{13} \mathrm{CO}_{2}+{ }^{12} \mathrm{CO}_{2}\right)+11 \mathrm{H}_{2} \mathrm{O} \rightarrow{ }^{(14+13+12)} \mathrm{C}_{6} \mathrm{H}_{22} \mathrm{O}_{11}+6 \mathrm{O}_{2}
$$

Theoretically, the ${ }^{14} \mathrm{C}$ atom produced in the atmosphere is quickly oxidized, as the partitioning between mono- and dioxide is 9 to 1 , meaning that $90 \%$ of atoms end up as ${ }^{14} \mathrm{CO}$ (Geyh and Schleicher 1990). The lifetime of carbon monoxide in the atmosphere is about 2 months, and with oxidation by a short-lived hydroxyl radical ${ }^{14} \mathrm{C}$, eventually results in ${ }^{14} \mathrm{CO}_{2}$. Therefore, the majority of ${ }^{14} \mathrm{C}$ atoms in the atmosphere are present in the form of dioxide. Any production variations of ${ }^{14} \mathrm{C}$ would therefore be quickly reflected in atmospheric ${ }^{14} \mathrm{CO}_{2}$ concentration. This procedure, however, may be interrupted by slow atmospheric mixing and/or abrupt changes of the Earth's geomagnetic field during the period between 8 and $10 \mathrm{kyr}$ BP (Figure 5).

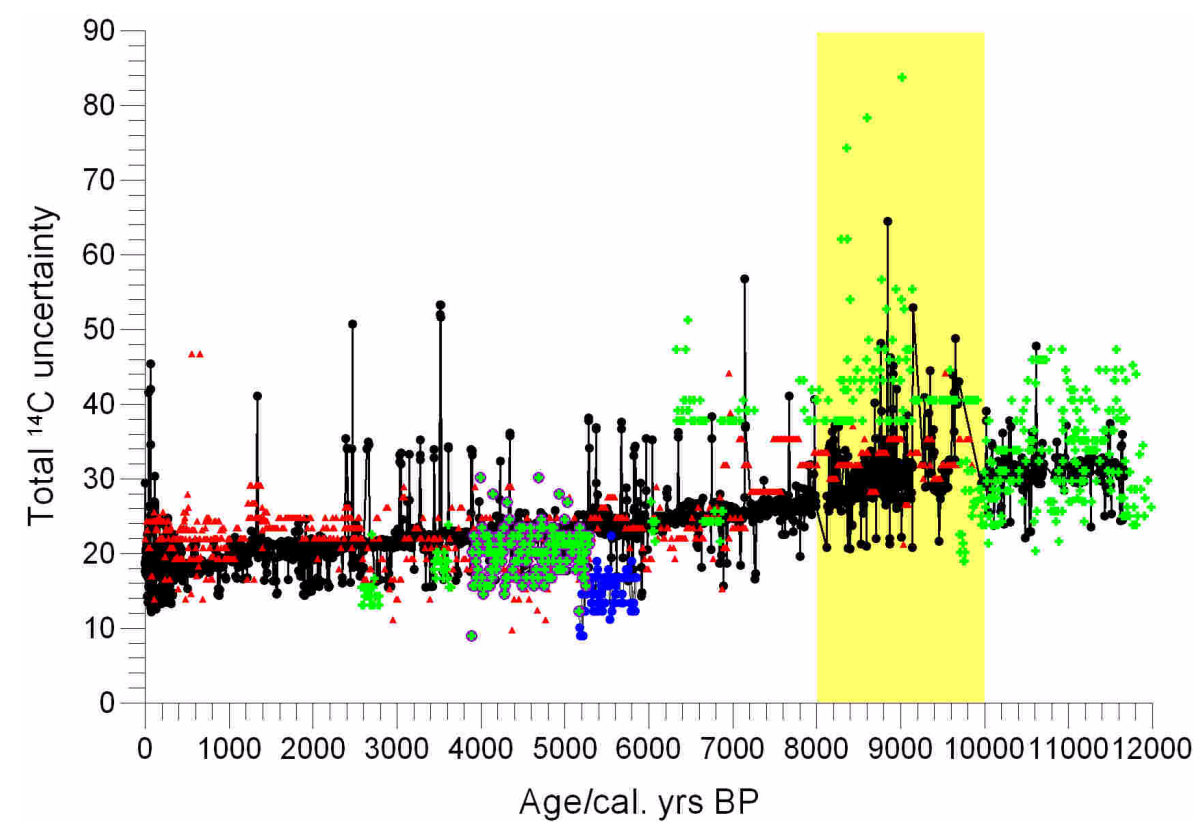

Figure 5 The total ${ }^{14} \mathrm{C}$ measurement uncertainty during last $11 \mathrm{kyr}$, in which the largest uncertainties appear between 8 and 10 kyr BP. Dark doted line: data of University of Washington (QL) tree rings; Red triangle line: data of Queen's University Belfast (UB) tree rings; Blue dotted line: data of University of Groningen (GrN) tree rings; Green crosses: data of Heidelberger Akademie der Wissenschaften (Hd) tree rings; Pink dots: data of CSIR, Pretoria (Pta) tree rings (data from Reimer et al. 2004; http://www.radiocarbon.org/IntCal04.htm). For interpretation of the references to color, the reader is referred to the online version of this article.

Long-term trends in ${ }^{14} \mathrm{C}$ concentration depend on the geomagnetic dipole moment (Stuiver et al. 1991; Stuiver and Braziunas 1993) that controls the intensity of cosmic rays reaching Earth's atmosphere and hence the ${ }^{14} \mathrm{C}$ production rate in the atmosphere. Although a geomagnetic field change does not affect the cosmic-ray flux at polar latitudes (Lal et al. 2005), the geomagnetic dipole moment changes over time (Yang et al. 2000), which modulates the cosmic-ray flux (Solanki et al. 2004). Study results show that the horizontal component of the magnetic force is greatest at low lat- 
itudes and minimal at high latitudes (Bard 1998). This leads to a weak effect on ${ }^{14} \mathrm{C}$ concentration at high latitudes and a strong one at low latitudes, which should have resulted in different impacts on the ${ }^{14} \mathrm{C}$ distribution in the atmosphere (Figure 6). If the ${ }^{14} \mathrm{CO}_{2} /{ }^{14} \mathrm{CO}$ ratio shift in Greenland, an indicator of cosmic-ray flux between 10 and $8 \mathrm{kyr}$ BP, does relate to the AUP at middle latitudes in the Northern Hemisphere, the tree-ring-deduced ${ }^{14} \mathrm{C}$ for the ${ }^{14} \mathrm{C}$ age calibration does not appear to correct the younger ${ }^{14} \mathrm{C}$ dates of the AUP interval to fit the age-depth regression line in the record of Lake Gun Nur, northern Mongolia.

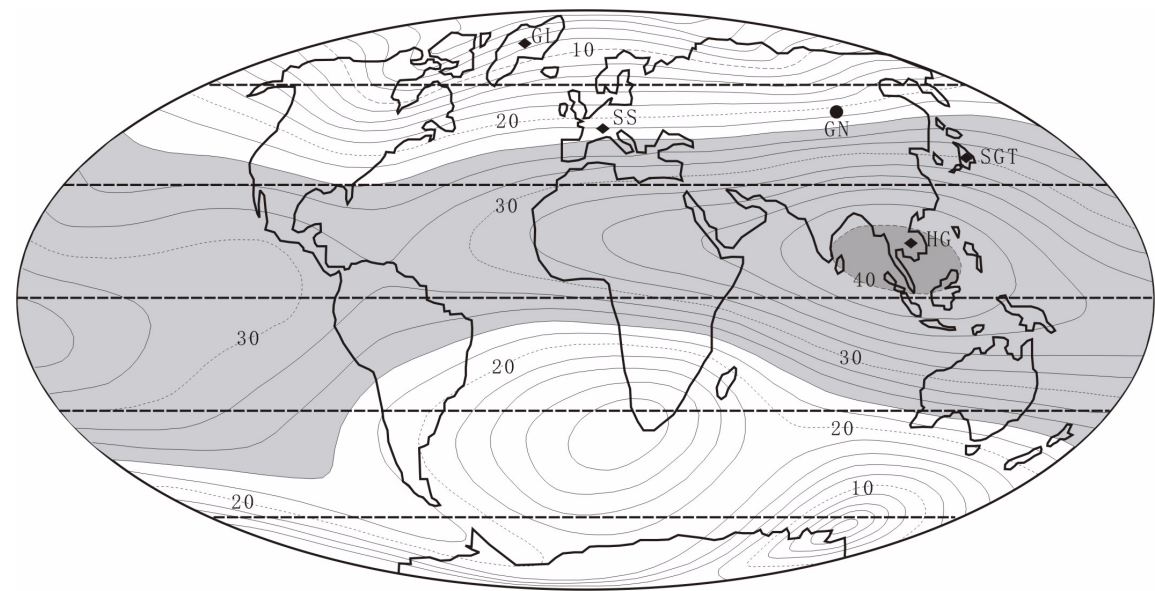

Figure 6 International geomagnetic reference field for the horizontal field component $\mathrm{H}$ expressed in $10^{3}$ gamma units (modified from Bard 1998). The figure shows that the horizontal component of the magnetic force is at a maximum in low latitudes (shaded zone) and at a minimum in high latitudes. This results in a weak effect on ${ }^{14} \mathrm{C}$ in high latitudes and a strong one in the low latitudes. Several sites mentioned in the text are marked in the figure (GL: Summit in Greenland; SS: Lake Soppensee in central Switzerland; GN: Lake Gun Nur in Mongolia; SGT: Lake Suigetsu in Japan; HG: Huguang Maar Lake in south China).

Certainly, the above hypothesis is just one explanation of the dating problems we observe. More work on both geological archives in different areas and on geochemical processes in the atmosphere needs to be undertaken to test our proposal, as recent studies show that nature may behave differently than previously thought (Zhang et al. 2006a,b; Engel et al. 2009).

\section{ACKNOWLEDGMENTS}

This study was co-supported by NSFC (No 40871096, U0933604 \& 40334038). AMS measurements were partially supported by the NSF-US (NSF-OISE98-06430 \& NSF-ESH04-02509). We owe Drs H Wang and J Quade for their detailed comments and suggestions on the manuscript, which improved the paper greatly.

\section{REFERENCES}

Bard E. 1998. Geochemical and geophysical implications of the radiocarbon calibration. Geochimica et Cosmochimica Acta 62(12):2025-38.

Bard E, Fairbanks R, Arnold M, Maurice P, Duprat J, Moyes J, Duplessy J-C. 1989. Sea-leave estimates during the last deglaciation based on $\delta^{18} \mathrm{O}$ and accelerator mass spectrometry ${ }^{14} \mathrm{C}$ ages measured in Glo- bierina bulloides. Quaternary Research 31(3):38191.

Bard E, Arnold M, Mangerud J, Paterne M, Labeyrie L, Duprat J, Mélières M-A, Sønstegaard E, Duplessy JC. 1994. The North Atlantic atmosphere-sea surface ${ }^{14} \mathrm{C}$ gradient during the Younger Dryas climatic event. Earth and Planetary Science Letters 126(4):275-87. 
Engel A, Möbius T, Bönisch H, Schmidt U, Heinz R, Levin I, Atlas E, Aoki S, Nakazawa T, Sugawara S, Moore F, Hurst D, Elkins J, Schauffle S, Andrews A Boering K. 2009. Age of stratospheric air unchanged within uncertainties over the past 30 years. Nature Geoscience 2(1):28-31.

Feng ZD, Wang WG, Guo LL, Khosbayar P, Narantsetseg T, Jull AJT, An CB, Li XQ, Zhang HC, Ma YZ. 2005. Holocene climate changes in the Mongolian Plateau: preliminary results. Quaternary International 136(1): 25-32.

Geyh MA, Schleicher H. 1990. Absolute Age Determination-Physical and Chemical Dating Methods and Their Application. Berlin: Springer-Verlag. p 162-80.

Hajdas I, Ivy SD, Beer J, Bonani G, Imboden D, Lotter AF, Sturm M, Suter M. 1993. AMS radiocarbon dating and varve chronology of Lake Soppensee: 6000 to $12000{ }^{14} \mathrm{C}$ years BP. Climate Dynamics 9(3):107-16.

Kitagawa H, van der Plicht J. 1998. A 40,000-year varve chronology from Lake Suigetsu, Japan: extension of the ${ }^{14} \mathrm{C}$ calibration curve. Radiocarbon 40(1): $505-15$.

Lal D, Jull AJT, Pollard D, Vacher L. 2005. Evidence for large century time-scale changes in solar activity in the past $32 \mathrm{kyr}$, based on in-situ cosmogenic ${ }^{14} \mathrm{C}$ in ice at Summit, Greenland. Earth and Planetary Science Letters 234(3-4):335-49.

Mingram J, Schettler G, Nowaczyk N, Luo XJ, Lu HY, Liu JQ, Negendank JFW. 2004. The Huguang maar lake - a high-resolution record of palaeoenvironmental and palaeoclimatic changes over the last 78,000 years from South China. Quaternary International 122(1):85-107.

Reimer PJ, Baillie MGL, Bard E, Bayliss A, Beck JW, Blackwell PG, Buck CE, Burr GS, Cutler KB, Damon PE, Edwards RL, Fairbanks RG, Friedrich M, Guilderson TP, Herring C, Hughen KA, Kromer B, McCormac G, Manning S, Bronk Ramsey C, Reimer RW, Remmele S, Southon JR, Stuiver M, Talamo S, Taylor FW, van der Plicht J, Weyhenmeyer C. 2004. IntCal04 terrestrial radiocarbon age calibration, $0-26 \mathrm{cal} \mathrm{kyr}$ BP. Radiocarbon 46(3):1029-58.
Ricketts RD, Johnson TC, Brown ET, Rasmussen KA, Romanovsky VV. 2001. The Holocene paleolimnology of Lake Issyk-Kul, Kyrgyzstan: trace element and stable isotope composition of ostracodes. Palaeogeography, Palaeoclimatology, Palaeoecology 176(1-4):207-27.

Sikes EL, Samson CR, Guilderson TP, Howard WR. 2000. Old radiocarbon ages in the southwest Pacific Ocean during the last glacial period and deglaciation. Nature 405(6786):555-9.

Solanki SK, Usoskin IG, Kromer B, Schüssler M, Beer J. 2004. Unusual activity of the Sun during recent decades compared to the previous 11,000 years. Nature 431(7012):1084-7.

Stuiver M, Braziunas T. 1993. Modeling atmospheric ${ }^{14} \mathrm{C}$ influences and ${ }^{14} \mathrm{C}$ ages of marine samples to 10,000 BC. Radiocarbon 35(1):137-89.

Stuiver M, Braziunas TF, Becker B, Kromer B. 1991. Climatic, solar, oceanic, and geomagnetic influences on Late-Glacial and Holocene atmospheric ${ }^{14} \mathrm{C} /{ }^{12} \mathrm{C}$ change. Quaternary Research 35:1-24.

Wang WG, Feng ZD, Lee XQ, Zhang HC, Ma YZ, An CB, Guo LL. 2004. Holocene abrupt climate shifts recorded in Gun Nur lake core, Northern Mongolia. Chinese Science Bulletin 49(5):520-26.

Yang S, Odah H, Shaw J. 2000. Variations in the geomagnetic dipole moment over the last 12000 years. Geophysical Journal International 140(1):158-62.

Zhang HC, Li B, Yang MS, Lei GL, Ding H, Niu J, Fan HF, Zhang WX, Chang FQ. 2006a. Dating paleosol and animal remains in loess deposits. Radiocarbon 48(1):109-16.

Zhang HC, Ming QZ, Lei GL, Zhang WX, Fan HF, Chang FQ, Wünnemann B, Hartman K. 2006b. Dilemma of dating on lacustrine deposits in a hyperarid inland basin of NW China. Radiocarbon 48(2):21926.

Zhang HC, Fan HF, Chang FQ, Zhang WX, Lei GL, Yang MS, Lei YB, Yang LQ. 2008. AMS dating on the shell bar section from Qaidam Basin, NE Tibetan Plateau, China. Radiocarbon 50(2):255-65. 